\title{
Pharmacokinetics of ibuprofen in man. I. Free and total area/dose relationships
}

\author{
Ibuprofen kinetics were studied in 15 subjects after four oral doses. Plasma levels of both total \\ and free ibuprofen were measured for $12 \mathrm{hr}$, and urine was collected for $48 \mathrm{hr}$ after the doses. \\ All subjects showed a nonlinear relationship between dose and total ibuprofen plasma AUC. \\ Free ibuprofen plasma $A U C$, however, was linearly related to the dose, suggesting that oral \\ clearance based on free drug was dose independent. Urinary recovery data indicated that \\ efficiency of absorption was dose independent.
}

\author{
G. F. Lockwood, Ph.D., K. S. Albert, Ph.D., W. R. Gillespie, M.S., G. G. Bole, M.D., \\ T. M. Harkcom, M.D., G. J. Szpunar, B.S., and J. G. Wagner, Ph.D. \\ Ann Arbor and Kalamazoo, Mich. \\ The College of Pharmacy, Upjohn Center for Clinical Pharmacology and Rackham Arthritis \\ Unit, The University of Michigan, Ann Arbor, and the Clinical Biopharmaceutics Research \\ Unit, The Upjohn Co., Kalamazoo
}

Ibuprofen $[d l$-2-( $p$-isobutylphenyl)propionic acid] is a propionic acid derivative with potent anti-inflammatory properties. It is used extensively in long-term oral treatment of rheumatoid arthritis and osteoarthritis. The pharmacology and metabolism of ibuprofen in man and other species have been reported. ${ }^{1,7}$ It has been demonstrated that ibuprofen is highly ( $>99 \%)$ plasma-protein bound. ${ }^{4,7,9}$ The manufacturer's package insert* presently specifies that ibuprofen shows nonlinear kinetics inasmuch as total plasma AUC increases less than proportionately with the given dose. Our aim was to discover the cause of the observed nonlinear kinetics.

\footnotetext{
Supported by a contract from The Upjohn Co.

Received for publication Nov. 26, 1982; accepted Jan. 18, 1983.

Reprint requests to: Dr. John G. Wagner, Upjohn Center for Clinical Pharmacology, The University of Michigan Medical Center, Ann Arbor, MI 48109

*Motrin, The Upjohn Co., Kalamazoo, Mich.
}

\section{Methods}

Our subjects were 15 white men ranging in age from 22 to $35 \mathrm{yr}$ (mean $=25$ ), with mean body weight, $78.2 \mathrm{~kg}$ (69.8 to 83.5$)$; height, $1.84 \mathrm{~m}$ (1.73 to 1.93$)$; and body surface area, $2.01 \mathrm{~m}^{2}$ ( 1.89 to 2.24 estimated by nomogram). The normal subjects were selected from respondents to an advertisement based on established criteria, namely, subject availability, reliability, medical history, physical examination, and the results of blood and urinary analyses. Subjects could not participate if they were taking other medications, had upper gastrointestinal diseases, were renally or hepatically impaired, or were known to be hypersensitive to ibuprofen. Subjects were asked to refrain from the use of other medications during the study. All subjects signed consent forms.

Each subject was assigned to one of three groups and received one of three treatments $(A$, $\mathrm{B}$, or $\mathrm{C}$ ) sequentially over the first $3 \mathrm{wk}$ of the 4-wk study period. Treatments $\mathrm{A}, \mathrm{B}$, and $\mathrm{C}$ 
Table I. Mean plasma concentrations of total and free ibuprofen with their SEs after one, two, and three 400-mg tablets

\begin{tabular}{c|ccc|c|c|c}
\hline \multirow{2}{*}{$\begin{array}{c}\text { Time } \\
(\mathrm{hr})\end{array}$} & \multicolumn{3}{|c|}{ Total concentration $(\mu \mathrm{g} / \mathrm{ml})$} & \multicolumn{3}{c}{ Free concentration $(\mathrm{ng} / \mathrm{ml})$} \\
\cline { 2 - 7 } & One tablet & Two tablets & Three tablets & One tablet & Two tablets & Three tablets \\
\hline 0.167 & 0.16 & 0.20 & 0.29 & 0.79 & 0.92 & 1.40 \\
& $(0.11)^{*}$ & $(0.14)$ & $(0.23)$ & $(0.56)$ & $(0.64)$ & $(1.16)$ \\
0.333 & 6.58 & 4.46 & 7.28 & 35.0 & 23.1 & 64.2 \\
& $(2.47)$ & $(1.66)$ & $(2.54)$ & $(14.0)$ & $(8.99)$ & $(26.16)$ \\
0.5 & 17.6 & 18.2 & 28.6 & 96.6 & 98.3 & 227 \\
& $(3.84)$ & $(3.96)$ & $(6.26)$ & $(22.0)$ & $(22.0)$ & $(72.8)$ \\
1.0 & 27.5 & 44.6 & 63.8 & 156 & 279 & 462 \\
& $(3.80)$ & $(5.54)$ & $(9.96)$ & $(22.6)$ & $(38.7)$ & $(78.8)$ \\
1.5 & 28.3 & 50.9 & 62.7 & 162 & 326 & 453 \\
& $(3.23)$ & $(4.10)$ & $(7.40)$ & $(22.0)$ & $(33.7)$ & $(64.2)$ \\
2.0 & 25.6 & 52.1 & 68.8 & 143 & 329 & 457 \\
& $(2.55)$ & $(2.15)$ & $(4.37)$ & $(15.6)$ & $(20.0)$ & $(43.7)$ \\
3.0 & 20.0 & 35.3 & 50.2 & 108 & 205 & 311 \\
& $(1.48)$ & $(2.34)$ & $(4.17)$ & $(9.42)$ & $(16.2)$ & $(36.9)$ \\
4.0 & 14.3 & 23.6 & 34.8 & 74.7 & 130 & 195 \\
& $(1.12)$ & $(1.81)$ & $(2.89)$ & $(6.86)$ & $(11.7)$ & $(20.5)$ \\
6.0 & 7.05 & 11.3 & 16.1 & 36.0 & 58.4 & 81.3 \\
& $(0.74)$ & $(0.78)$ & $(1.47)$ & $(4.09)$ & $(4.71)$ & $(8.37)$ \\
8.0 & 3.48 & 5.68 & 7.71 & 17.5 & 28.7 & 38.1 \\
& $(0.41)$ & $(0.53)$ & $(0.71)$ & $(2.27)$ & $(2.95)$ & $(3.94)$ \\
10.0 & 1.95 & 2.84 & 4.09 & 9.73 & 14.1 & 19.8 \\
& $(0.22)$ & $(0.35)$ & $(0.36)$ & $(1.19)$ & $(1.85)$ & $(1.93)$ \\
12.0 & 1.14 & 1.80 & 2.04 & 5.98 & 8.90 & 11.0 \\
& $(0.17)$ & $(0.28)$ & $(0.31)$ & $(0.83)$ & $(1.40)$ & $(1.26)$ \\
\hline
\end{tabular}

* Numbers in parentheses are SEs.

consisted of one, two, or three 400-mg ibuprofen tablets (Motrin), which were given to the groups in accordance with a Latin square design. In the final week of the study all subjects received treatment $\mathrm{D}$, which consisted of $20 \mathrm{ml}$ oral ibuprofen solution ( $20 \mathrm{mg} / \mathrm{ml}$ ibuprofen). All medication was taken with 6 ounces of water, and tablets were swallowed whole. All medication was taken at 7 A.M., the subjects having fasted since 10 P.M. the previous night. No food or beverages were permitted until $4 \mathrm{hr}$ after the drug was given, at which time a standard lunch was provided. Assay of the dosage forms before the drug was given showed that actual doses were as follows: treatment $A, 401$ $\mathrm{mg}$; treatment B, $802 \mathrm{mg}$; treatment C, 1203 $\mathrm{mg}$; and treatment $\mathrm{D}, 420 \mathrm{mg}$. These doses were used in the estimation of clearance $(\mathrm{Cl})$ and urinary recovery.

Blood samples were drawn by sequential venipuncture into Vacutainer tubes containing di- sodium edetate as an anticoagulant. For treatments $\mathrm{A}$ to $\mathrm{C}, 5-\mathrm{ml}$ blood samples were drawn at $0,0.167,0.33,3,10$, and $12 \mathrm{hr}$, and $10-\mathrm{ml}$ samples were drawn at $0.5,1,1.5,2,4,6$, and $8 \mathrm{hr}$. For treatment $\mathrm{D}, 5-\mathrm{ml}$ blood samples were drawn at $0,0.083,0.167,0.25,0.333$, and 3 $\mathrm{hr}$, and $10-\mathrm{ml}$ samples were drawn at $0.5,1$, $1.5,2,4,6$, and $8 \mathrm{hr}$. The sampling scheme after the tablets was different from that following the solution, since we knew from previous studies that the drug in solution is absorbed more rapidly than the drug in tablet form. Each blood sample was rapidly separated into plasma and cellular components by centrifugation and the plasma was then harvested and frozen until assayed. Plasma obtained from the $10-\mathrm{ml}$ blood samples was divided into two aliquots; half was used for the HPLC plasma ibuprofen assay and half for the ibuprofen protein-binding study.

Total urine samples were collected over the following intervals: 0 to 6,6 to 12,12 to 24,24 
to 36 , and 36 to $48 \mathrm{hr}$. The volume of each sample was recorded and a 50-ml aliquot of each was frozen until just before it was assayed.

The 13 plasma samples obtained from each subject during each phase were subjected to specific HPLC assay for ibuprofen as previously described. ${ }^{5}$ Urine samples were assayed for free and conjugated drug and metabolites by the previously described gradient HPLC system. ${ }^{5}$

An estimation of free ibuprofen concentrations in plasma samples was gained by subjecting 7 of the 13 samples to equilibrium dialysis and then using these data and the HPLC assays on the other samples to estimate free concentrations for all samples. A detailed account of methods will be presented in a future report ${ }^{6}$ and is also explained by equations No. 5 and No. 10 of Behm and Wagner. ${ }^{2}$

\section{Results}

Mean plasma concentrations of both total and free ibuprofen after one, two, and three tablets are listed in Table I. Mean plasma concentrations of both total and free ibuprofen after the oral solution are listed in Table II. It should be noted that the one-compartment open model elaborated from mean plasma concentrations differs from the two-compartment open model elaborated from individual subject plasma concentrations, as will be discussed in a future report.

Table III lists kinetic parameters obtained from total and free ibuprofen plasma concentrations. The observed area under the plasma concentration-time curve, (AUC 0-T, where $\mathrm{T}=12 \mathrm{hr}$ for tablets and $8 \mathrm{hr}$ for solution), averaged $98 \%$ (range $96 \%$ to $99 \%$ ) of the estimated AUC $0-\infty$. Hence the area estimated by extrapolation, namely AUC $\mathrm{T}-\infty$, was only a minor portion of AUC $0-\infty$.

In Table III there are eight mean elimination rate constants. An analysis of variance of all the individual elimination rate constants $(n=120)$ indicated no significant differences between the overall mean rate constant for total drug $(0.316$ $\mathrm{hr}^{-1}$ ) and the overall mean rate constant for free drug $\left(0.310 \mathrm{hr}^{-1} ; \mathrm{P}>.05\right)$. In contrast, significant differences were observed among treatment means $(P<0.001)$. In addition, the mean rate constant for tablets based on free ibuprofen
Table II. Mean plasma concentrations of total and free ibuprofen with their SEs after aqueous solution

\begin{tabular}{c|c|c}
\hline \multirow{2}{*}{$\begin{array}{c}\text { Time } \\
(\mathrm{hr})\end{array}$} & \multicolumn{2}{|c}{ Plasma concentration of ibuprofen } \\
\cline { 2 - 3 } & $\begin{array}{c}\text { Total } \\
(\mu \mathrm{g} / \mathrm{ml})\end{array}$ & $\begin{array}{c}\text { Free } \\
(\mathrm{ng} / \mathrm{ml})\end{array}$ \\
\hline 0.0833 & 12.5 & 66.4 \\
& $(2.32)^{*}$ & $(13.5)$ \\
0.167 & 26.5 & 153 \\
& $(4.24)$ & $(28.0)$ \\
0.25 & 33.0 & 195 \\
& $(4.24)$ & $(28.5)$ \\
0.333 & 37.4 & 226 \\
& $(4.29)$ & $(29.6)$ \\
0.5 & 36.2 & 214 \\
& $(3.00)$ & $(20.0)$ \\
1.0 & 33.2 & 193 \\
& $(2.20)$ & $(14.8)$ \\
1.5 & 30.2 & 171 \\
& $(1.68)$ & $(11.2)$ \\
2.0 & 23.9 & 130 \\
& $(1.09)$ & $(6.01)$ \\
3.0 & 16.3 & 86.5 \\
& $(0.66)$ & $(3.66)$ \\
4.0 & 11.7 & 60.3 \\
& $(0.64)$ & $(3.52)$ \\
6.0 & 5.82 & 29.1 \\
& $(0.46)$ & $(2.25)$ \\
8.0 & 3.09 & 15.9 \\
& $(0.32)$ & $(1.66)$ \\
\hline
\end{tabular}

*Numbers in parentheses are SEs.

plasma concentrations $\left(0.297 \mathrm{hr}^{-1}\right)$ differed significantly $(P<0.05)$ from the corresponding mean rate constant for the solution $(0.349$ $\left.\mathrm{hr}^{-1}\right)$. Considering the relative magnitudes of the mean rate constants, a likely explanation is that there is some continued absorption after the tablets in the time range in which elimination rate constants were estimated (usually the last three or four points). Thus rate constants from the solution are the most reliable. Mean rate constants following the solution, namely 0.370 $\mathrm{hr}^{-1}$ from total ibuprofen and $0.349 \mathrm{hr}^{-1}$ from free ibuprofen, correspond to harmonic mean elimination $t^{1 / 2} \mathrm{~s}$ of $1.87 \mathrm{hr}$ and $1.98 \mathrm{hr}$.

Oral Cls were calculated as the ratio of dose by assay per kilogram of body weight to the AUC $0-\infty$. Values listed in Table III are oral Cls averaged over treatments. Fig. $1, a$, is a plot of individual oral $\mathrm{Cl}$ from total drug $(l / \mathrm{kg} \times \mathrm{hr})$ vs assay dose $(\mathrm{mg} / \mathrm{kg})$. The line drawn through the 
Table III. Mean kinetic parameters obtained from total and free ibuprofen plasma concentrations

\begin{tabular}{|c|c|c|c|c|}
\hline \multirow[b]{2}{*}{ Parameter } & \multicolumn{4}{|c|}{ Mean $(S E)$} \\
\hline & One tablet & Two tablets & Three tablets & Solution \\
\hline $\begin{array}{l}\text { Peak total plasma concentration } \\
(\mu \mathrm{g} / \mathrm{ml})\end{array}$ & $\begin{array}{c}37.7 \\
(2.16)\end{array}$ & $\begin{array}{c}61.1 \\
(2.47)\end{array}$ & $\begin{array}{c}87.7 \\
(4.84)\end{array}$ & $\begin{array}{c}43.8 \\
(2.83)\end{array}$ \\
\hline $\begin{array}{l}\text { Peak free plasma concentration } \\
(\mathrm{ng} / \mathrm{ml})\end{array}$ & $\begin{array}{c}221 \\
(15.9)\end{array}$ & $\begin{array}{c}403 \\
(23.5)\end{array}$ & $\begin{array}{c}688 \\
(54.2)\end{array}$ & $\begin{array}{c}269 \\
(22.2)\end{array}$ \\
\hline $\begin{array}{l}\text { Time of peak concentration } \\
(\mathrm{hr})\end{array}$ & $\begin{array}{c}1.3 \\
(0.23)\end{array}$ & $\begin{array}{c}1.6 \\
(0.15)\end{array}$ & $\begin{array}{l}1.7 \\
(0.21)\end{array}$ & $\begin{array}{c}0.71 \\
(0.14)\end{array}$ \\
\hline$(\text { AUC } 0-\mathrm{T})_{\mathrm{t}}\left(\frac{\mu \mathrm{g}}{\mathrm{ml}} \times \mathrm{hr}\right)$ & $\begin{array}{c}122 \\
(4.85)\end{array}$ & $\begin{array}{c}206 \\
(7.71)\end{array}$ & $\begin{array}{c}286 \\
(12.3)\end{array}$ & $\begin{array}{c}121 \\
(4.69)\end{array}$ \\
\hline$(\mathrm{AUC} 0-\mathrm{T})_{\mathrm{f}}\left(\frac{\mathrm{ng}}{\mathrm{ml}} \times \mathrm{hr}\right)$ & $\begin{array}{c}656 \\
(30.6)\end{array}$ & $\begin{array}{c}1197 \\
(51.7)\end{array}$ & $\begin{array}{c}1780 \\
(82.7)\end{array}$ & $\begin{array}{c}664 \\
(27.3)\end{array}$ \\
\hline$\left(\mathrm{AUC} 0-x_{\mathrm{t}}\left(\frac{\mu \mathrm{g}}{\mathrm{ml}} \times \mathrm{hr}\right)\right.$ & $\begin{array}{c}126 \\
(5.12)\end{array}$ & $\begin{array}{c}212 \\
(7.89)\end{array}$ & $\begin{array}{c}293 \\
(12.9)\end{array}$ & $\begin{array}{c}121 \\
(4.69)\end{array}$ \\
\hline$(\text { AUC } 0-\infty)_{\mathrm{r}}\left(\frac{\mathrm{ng}}{\mathrm{ml}} \times \mathrm{hr}\right)$ & $\begin{array}{c}680 \\
(31.7)\end{array}$ & $\begin{array}{c}1229 \\
(55.1)\end{array}$ & $\begin{array}{r}1816 \\
(86.4)\end{array}$ & $\begin{array}{c}711 \\
(30.8)\end{array}$ \\
\hline $\begin{array}{l}\text { Elimination rate constant from } \\
\text { total }\left(\mathrm{hr}^{-1}\right)\end{array}$ & $\begin{array}{c}0.273 \\
(0.0066)\end{array}$ & $\begin{array}{c}0.304 \\
(0.018)\end{array}$ & $\begin{array}{c}0.319 \\
(0.012)\end{array}$ & $\begin{array}{c}0.370 \\
(0.014)\end{array}$ \\
\hline $\begin{array}{l}\text { Elimination rate constant from free } \\
\left(\mathrm{hr}^{-1}\right)\end{array}$ & $\begin{array}{c}0.271 \\
(0.012)\end{array}$ & $\begin{array}{c}0.307 \\
(0.015)\end{array}$ & $\begin{array}{c}0.314 \\
(0.015)\end{array}$ & $\begin{array}{c}0.349 \\
(0.015)\end{array}$ \\
\hline $\mathrm{Cl}_{\mathrm{t}}^{*}$ of total $l /(\mathrm{kg} \times \mathrm{hr})$ & $\begin{array}{l}0.0419 \\
(0.002)\end{array}$ & $\begin{array}{l}0.0498 \\
(0.003)\end{array}$ & $\begin{array}{l}0.0541 \\
(0.003)\end{array}$ & $\begin{array}{l}0.0426 \\
(0.001)\end{array}$ \\
\hline $\mathrm{Cl}_{\mathrm{f}} *$ of free $l /(\mathrm{kg} \times \mathrm{hr})$ & $\begin{array}{l}7.83 \\
(0.42)\end{array}$ & $\begin{array}{l}8.63 \\
(0.45)\end{array}$ & $\begin{array}{l}8.77 \\
(0.42)\end{array}$ & $\begin{array}{l}7.75 \\
(0.26)\end{array}$ \\
\hline
\end{tabular}

*Oral Cls are more properly written as $\mathrm{Cl}_{\mathrm{l}} / \mathrm{F}$ and $\mathrm{Cl}_{\mathrm{f}} / \mathrm{F}$ where $\mathrm{F}$ is bioavailability.

points is the least squares regression line; clearance from total plasma concentrations $\left(\mathrm{Cl}_{\mathrm{t}}\right)=$ $0.0349+0.00134$ (dose). The slope of this line differed from zero $(\mathrm{P}<0.001)$ by a $t$ test. An analysis of variance showed highly significant differences among treatment means $(\mathrm{P}<$ 0.0001 ). A paired $t$ test, however, showed that the difference between mean Cls of 0.0419 and $0.0426 \mathrm{l} / \mathrm{kg} \times \mathrm{hr}$ for total drug after one tablet and the solution was not significant $(P>0.25)$. This indicated that $\mathrm{Cl}$ of total drug was dose dependent, with values increasing as the dose increased. An analysis of variance of oral $\mathrm{Cl}$ from free drug also showed significant differences among treatment means $(P=0.019)$. At equivalent doses, however, a paired $t$ test showed that differences between the mean $\mathrm{Cl}$ of 7.83 and $7.75 \mathrm{l} / \mathrm{kg} \times \mathrm{hr}$ for free drug after one tablet and the solution were not significant $(\mathrm{P}>0.25)$. In addition, a plot of free $\mathrm{Cl}$ $(l / \mathrm{kg} \times \mathrm{hr})$ vs assay dose $(\mathrm{mg} / \mathrm{kg}$ ) (Fig. $1, b)$ resulted in a regression with a slope that was not significantly different from zero $(0.1>\mathrm{P}>$ 0.05 ). These results suggested that there was a small dose dependency for $\mathrm{Cl}$ based on free drug. Since oral $\mathrm{Cl}$ from free drug is the true $\mathrm{Cl}$ divided by the bioavailability, one possible explanation for the observed dependence of oral free $\mathrm{Cl}$ on dose is a slight decrease in the efficiency of absorption as the dose is increased. Estimates of bioavailability of one, two, and three tablets relative to the aqueous solution (calculated as ratios of free oral Cls) of $99 \%$, $90 \%$, and $89 \%$ support this premise. Urinary recoveries of ibuprofen and its major metabolites, however, were consistent from treatment to treatment (Table IV). This indicates that urinary excretion of ibuprofen and its metabolites was a linear function of dose and any dose dependency associated with the absorption process was minor.

Semilogarithmic plots of individual subject total and free plasma concentrations of ibuprofen following one, two, and three tablets were constructed (not shown). In all cases it was found that the higher concentrations lie above the extrapolated log linear line that could be drawn through the terminal concentrations. This suggests applicability of the two-compartment open model with first-order absorption with rate 

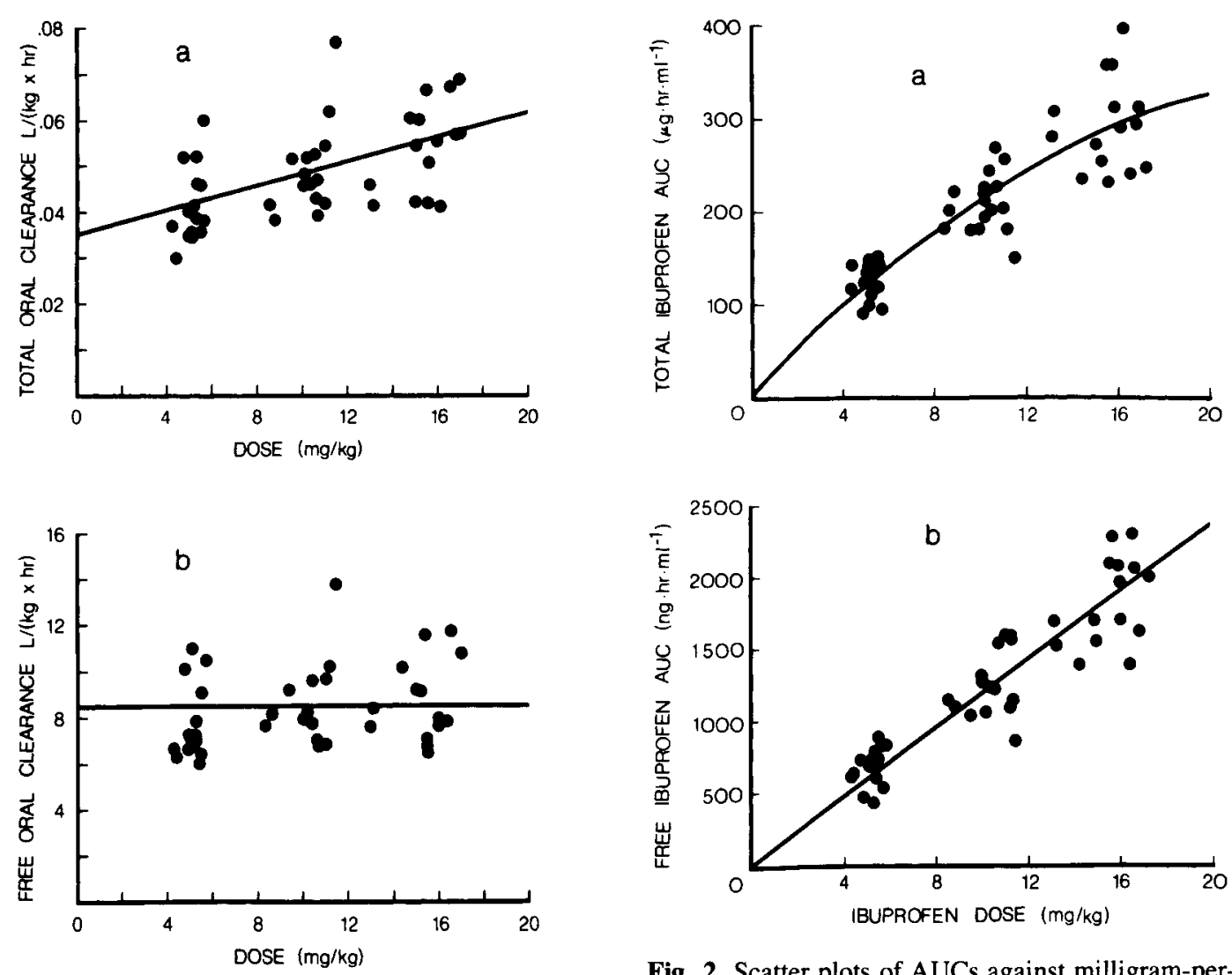

Fig. 1. Plot of oral Cls against milligram-per-kilogram dose. $a$, Regression of oral $\mathrm{Cl}$ for total drug on dose. Least squares line has the equation $\mathrm{Y}=$ $0.0349+0.001335 \mathrm{X}, \mathrm{r}=0.564(\mathrm{P}<0.001) . b$, Regression of oral $\mathrm{Cl}$ from free drug on dose $r=0.261(0.1>P>0.05)$. Line drawn represents mean $\mathrm{Cl}$ of $8.41 \mathrm{l} /(\mathrm{kg} \times \mathrm{hr})$.

constant for absorption $\left(k_{\mathrm{a}}\right)>_{\alpha}>_{\beta}$, and this will be shown in a future report.

We knew that the area under the total ibuprofen plasma concentration curve, (AUC $0-\infty)_{t}$, increased less than proportionately with increases in dose. The mean (AUC $0-\infty)_{t}$ values in Table III support this observation. Fig. 2, $a$, is a plot of individual subject (AUC $0-\infty$ ) values vs the drug dose measured in milligrams per kilogram. The line drawn through the points is empirical and is based on the least squares parabola forced through the origin (equation 1).

$$
(\text { AUC } 0-\infty)_{\mathrm{t}}=26.6(\text { dose })-0.517(\text { dose })^{2}
$$

This should not be considered a predictive function, particularly outside the dose range

Fig. 2. Scatter plots of AUCs against milligram-perkilogram dose. $a$, Total ibuprofen plasma AUC against dose. Curvilinear relationship is described by equation 1 in the text. $b$, Similar plot of free areas against dose. In this plot the function that best describes data is given as equation 2 .

studied, but it does indicate the curvature in the data, particularly when theory indicates that (AUC $0-\infty)_{t}$ should be equal to zero when the dose is equal to zero.

Fig. 2, $b$, is a plot of individual subject area under the free ibuprofen plasma concentrationtime curve (AUC $0-\infty)_{\mathrm{f}}$ against the milligramper-kilogram drug dose. No curvature was evident, suggesting a linear relationship between free plasma concentrations of ibuprofen and the dose given. The equation of the line in Fig. 2, $b$, is:

$$
(\text { AUC } 0-\infty)_{\mathrm{f}}=118(\text { dose })
$$

\section{Discussion}

Data presented indicate that nonlinearity of total ibuprofen plasma concentration data is the 
Table IV. Summary of urinary excretion data

\begin{tabular}{l|c|c|c|c}
\hline \multirow{2}{*}{ Compound(s) } & \multicolumn{4}{|c}{ Mean percent recovery in urine* } \\
\cline { 2 - 5 } & One tablet & Two tablets & Three tablets & Solution \\
\hline Unchanged ibuprofen & 0 & 0.12 & 0.31 & 0 \\
Conjugated ibuprofen & & $(0.085) \dagger$ & $(0.27)$ & \\
& 13.7 & 11.3 & 10.7 & 13.0 \\
Hydroxy metabolite $\neq$ & $(0.82)$ & $(1.11)$ & $(0.83)$ & $(1.32)$ \\
& 11.2 & 10.3 & 11.4 & 11.9 \\
Conjugated hydroxy metabolite & $(0.59)$ & $(0.72)$ & $(0.57)$ & $(1.45)$ \\
Carboxy metabolite§ & 17.0 & 16.2 & 13.8 & 12.4 \\
& $(0.98)$ & $(1.55)$ & $(1.19)$ & $(1.39)$ \\
Conjugated carboxy metabolite & 30.1 & 27.7 & 30.9 & 27.2 \\
& $(1.60)$ & $(1.29)$ & $(1.24)$ & $(2.30)$ \\
Total recovery & 12.9 & 12.0 & 10.3 & 11.2 \\
& $(1.42)$ & $(1.63)$ & $(1.73)$ & $(1.88)$ \\
& 84.9 & 77.7 & 77.4 & 75.7 \\
& $(3.02)$ & $(3.92)$ & $(3.46)$ & $(5.03)$ \\
\hline
\end{tabular}

*There were no significant differences among treatment means for one, two, and three tablets in any given row when data were analyzed by analysis of variance for crossover design.

†Numbers in parentheses are SEs.

‡Structure of carboxy metabolite: $\mathrm{H}_{3} \mathrm{C}$

$\S$ Structure of hydroxy metabolite: HOOC

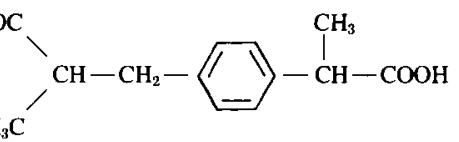

consequence of nonlinear plasma protein binding of the drug. Although plots of total area against dose exhibit curvature (Fig. 2, $a$ ), plots of free area against dose are linear, and the line passes through the origin (Fig. 2, $b$ ). As a consequence of the nonlinear plasma protein binding (which will be discussed in detail in a future report), both the oral $\mathrm{Cl}$ and bioavailability estimated from total plasma concentrations are dose dependent. Both the oral $\mathrm{Cl}$ and bioavailability estimated from free plasma concentrations, however, are virtually dose independent.

The consistency of the mean urinary recoveries shown in Table IV, coupled with the statistical analyses of the complete data, indicated that urinary excretion of the ibuprofen metabolites was a linear function of dose and was consequently dose independent. These results, together with Fig. $2, b$, and the $\mathrm{Cl}_{\mathrm{f}}$ results shown in Table III, suggest that the efficiency of absorption of ibuprofen is dose independent.

The dose dependence of the apparent elimination rate constants was probably observed when absorption continued, to a minor degree, into the time region where rate constants were estimated, particularly for the tablet treatments. To ensure that this was introducing little if any bias into the estimated oral Cls, we also calculated the extrapolated areas (AUC $T-\infty)_{t}$ and (AUC $\mathrm{T}-\infty)_{\mathrm{f}}$ by dividing the observed plasma concentration at $12 \mathrm{hr}$ (for tablets) by the elimination rate constant obtained for the same subject after the solution was given. The resulting mean $\mathrm{Cls}, \mathrm{Cl}_{\mathrm{t}}$, were $0.0417,0.0494$, and $0.0541 / /(\mathrm{kg} \times \mathrm{hr})$ for one, two, and three tablets, compared with the values 0.0419 , 0.0498 , and $0.0541 l /(\mathrm{kg} \times \mathrm{hr})$, shown in Table III and calculated by rate constants estimated from the tablet data. Similarly, by the revised method, mean $\mathrm{Cls}, \mathrm{Cl}_{\mathrm{f}}$, were 7.97 , 8.49 , and $8.83 l /(\mathrm{kg} \times \mathrm{hr})$ for one, two, and three tablets, compared with $7.83,8.63$, and $8.77 \mathrm{l} /(\mathrm{kg} \times \mathrm{hr})$, shown in Table III. Thus the extrapolated area relative to the total area is so small that the error introduced by a biased elimination rate constant is small and lacks significance. Both free and total ibuprofen plasma concentrations, at the tail end of the curves, 
declined exponentially at essentially the same rates, which has been explained theoretically by Wagner $^{8}$ and Gibaldi and McNamara. ${ }^{3}$ No metabolites were detected in plasma.

\section{References}

1. Adams SS, Cliffe EE, Lessel B, Nicholson JS: Some biological properties of 2-(4-isobutylphenyl)propionic acid. J Pharm Sci 56: 1686, 1967.

2. Behm HL, Wagner JG: Errors in the interpretation of data from equilibrium dialysis protein-binding experiments. Res Commun Chem Pathol Pharmacol 26: 145-160, 1979.

3. Gibaldi M, McNamara PJ: Apparent volumes of distribution and drug binding to plasma proteins and tissues. Eur J Clin Pharmacol 13:373-378, 1978.

4. Kober A, Sjoholm I: The binding sites on human serum albumin for some nonsteroidal anti-inflammatory drugs. Mol Pharmacol 18:421-426, 1980
5. Lockwood GF, Wagner JG: High performance liquid chromatographic determination of ibuprofen and its major metabolites in biological fluids. J Chromatogr 232:335-343, 1982.

6. Lockwood GF, Albert KS, Gillespie WR, Szpunar GS, Wagner JG: Pharmacokinetics of ibuprofen in man. III. Plasma protein binding. (Submitted for publication.)

7. Mills RFN, Adams SS, Cliffe EE, Dickinson W, Nicholson JS: The metabolism of ibuprofen. Xenobiotica 3:589-598, 1973.

8. Wagner JG: Simple model to explain effects of plasma protein binding and tissue binding on calculated volumes of distribution, apparent elimination rate constants and clearances. Eur J Clin Pharmacol 10:425-432, 1976.

9. Whitlam JB, Crooks MJ, Brown KF, Veng Pedersen P: Binding of nonsteroidal anti-inflammatory agents to proteins. I. Ibuprofen-serum albumin interaction. Biochem Pharmacol 28: $675-678,1979$. 